\title{
MEDIA PEMBELAJARAN SEBAGAI SARANA KOMUNIKASI MATEMATIKA DI SEKOLAH DASAR
}

\author{
Rivdya Eliza \\ Fakultas Tarbiyah IAIN Imam Bonjol Padang \\ Korespondensi: Jl. Mahmud Yunus Lubuk Lintah Padang, Sumatera Batrat
}

\begin{abstract}
Rapid developments in information technology and communication today is based on the development of mathematics in the field of number theory, algebra, analysis, theory of chances and discrete mathematics. To master the technology and creating future required a strong mastery of mathematics from an early age. Standard mathematical competence and basic competence in elementary school (SD), Junior Secondary School (SMP) and High School (SMA) have been prepared with the intention to develop the ability to use mathematics in solving problems and communicating the idea or the idea of using symbols, tables, diagrams, and other media. At the elementary school where children are in the concrete operational stage and how to effectively communicate the idea of mathematical ideas is to use instructional media. This paper will try to review the instructional media as one means of communication of mathematics learning in elementary school (SD).
\end{abstract}

Kata kunci: komunikasi, media pembelajaran

\section{PENDAHULUAN}

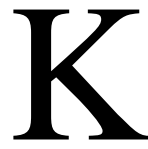

emampuan mengkomunikasikan ide dan pendapat akan seC ngan semakin kuatnya tuntutan keterbukaan dan akuntabilitas dari setiap lembaga. Itulah sebabnya, sejak tahun 2000 , NCTM mendeklarasikan bahwa program pembelajaran di kelas-kelas TK sampai SMA atas di Amerika Serikat harus memberi kesempatan kepada para siswa untuk mengkomunikasikan pemikiran matematika mereka secara logis dan jelas kepada teman sejawatnya, gurunya, dan orang lain; di samping memberi kesempatan para siswa untuk menganalisis dan mengevaluasi pemikiran matematika orang lain, serta memberi kesempatan untuk menggunakan bahasa matematika untuk menyatakan ide-ide mereka dengan tepat (Shadiq: 2004). Tentu hal yang sama juga berlaku di Indonesia karena sifat matematika yang universal.

Pada dasarnya secara individual manusia itu berbeda-beda, demikian pula dalam memahami konsep-konsep abstrak, yang bisa dicapai melalui tingkattingkat belajar yang berbeda. Namun ada suatu keyakinan bahwa siswa khususnya siswa di sekolah dasar (SD) pada kelas rendah belajar melalui dunia nyata dan memanipulasikan benda-benda sebagai perantaranya. Bahkan tidak sedikit pula orang dewasa yang umumnya sudah memahami konsep abstrak, tetapi pada situasi-situasi tertentu masih memerlu- 
kan benda-benda perantara (Ruseffendi, dkk, 1993).

Setiap konsep abstrak dalam matematika yang baru dipahami oleh siswa SD perlu segera diberikan penguatan supaya mengendap, melekat dan tahan lama tertanam sehingga menjadi miliknya dalam pola pikir maupun pola tindaknya. Untuk keperluan inilah maka diperlukan belajar melalui berbuat dan pengertian, tidak hanya sekedar hafalan atau mengingat fakta saja yang tentunya akan mudah dilupakan dan sulit untuk dapat dimiliki. Karena itulah maka dalam pengajaran matematika baik di Sekolah Dasar (SD) sangat diperlukan alat peraga atau media pembelajaran sebagai salah satu alat untuk mengkomunikasikan ide atau gagasan.

Media dalam kegiatan proses belajar mengajar berfungsi sebagai instrumental, dengan kata lain, media berarti hanya sekedar 'alat' saja, bukan tujuan. Alat untuk membantu proses belajar, alat untuk mempermudah pemahaman masalah yang sedang dibahas, alat untuk mempermudah mengkomunikasikan halhal yang rumit. Setiap media memiliki ciri (karakteristik), memiliki kekhasannya masing-masing, sehingga hanya tepat digunakan untuk tujuan-tujuan yang khas dan sesuai pula.

\section{KOMUNIKASI DALAM MATE- MATIKA}

Suriasumantri (1988) menulis: "Matematika adalah bahasa yang melambangkan serangkaian makna dari pernyataan yang ingin kita sampaikan. Lambang-lambang matematika bersifat "artifisial" yang baru mempunyai arti setelah sebuah makna diberikan padanya."Sebagai contoh, notasi $20 \times 3$ dapat digunakan untuk menyatakan berbagai hal berikut:

1. Jarak tempuh sepeda motor selama 3 jam dengan kecepatan 20 $\mathrm{km} / \mathrm{jam}$
2. Luas permukaan kolam dengan ukuran panjang $20 \mathrm{~m}$ dan lebar 3 meter

3. Banyak roda pada 20 buah becak.

Contoh di atas telah menunjukkan bahwa suatu notasi $20 \times 3$ dapat menyatakan suatu hal yang berbeda. Selain itu, lambang, gambar dan tabel dapat juga di gunakan untuk menyampaikan informasi. Jika siswa tidak mempelajari matematika, siswa akan kesulitan menyatakan jarak tempuh sepeda motor selama waktu dan kecepatan tertentu. Siswa juga akan kesulitan menentukan luas permukaan kolam, menghitung roda becak dan lain sebagainya.

Depdiknas (2002) menyatakan: "Banyak persoalan ataupun informasi disampaikan dengan bahasa matematika, misalnya menyajikan persoalan atau masalah ke dalam model matematika yang dapat berupa diagram, persamaan matematika, grafik, ataupun tabel. Mengkomunikasikan gagasan dengan bahasa matematika justru lebih praktis, sistematis, dan efisien. Begitu pentingnya matematika sehingga bahasa matematika merupakan bagian dari bahasa yang digunakan dalam masyarakat." Hal ini sesungguhnya telah membenarkan laporan Cockroft bahwa siswa harus belajar matematika dengan alasan bahwa matematika merupakan alat komunikasi yang sangat kuat dan berpengaruh (powerful), teliti dan tepat (concise), dan tidak membingungkan (unambiguous).

Hingga saat ini, Standar kompetensi dan kompetensi dasar matematika pada tingkat Sekolah Dasar (SD), Sekolah Menengah Pertama (SMP) dan Sekolah Menengah Atas (SMA) disusun dengan masih tetap dengan maksud untuk mengembangkan kemampuan menggunakan matematika dalam pemecahan masalah dan mengkomunikasikan ide atau gagasan dengan menggunakan simbol, tabel, diagram, dan media lain. Kemampuan matematika yang dipilih serta ditetapkan sudah dirancang sesuai 
dengan kemampuan dan kebutuhan siswa agar dapat berkembang secara optimal, maka kompetensi yang berkaitan dengan komunikasi ini harus dicapai selama proses pembelajaran sedang berlangsung di kelas.

Sekali lagi, kegiatan mengkomunikasikan hasil dan proses belajar dan menemukan ide-ide matematika ini akan menjadi sangat penting karena akan tetap digunakan para siswa baik ketika mereka masih duduk di bangku sekolah dan universitas, ataupun ketika mereka sudah meninggalkan bangku sekolah untuk bekerja.

\section{MEDIA PEMBELAJARAN}

\section{Pengertian Media Pembelajaran}

Media disebut juga alat-alat audio visual, artinya alat yang dapat dilihat dan didengar yang dipakai dalam proses pembelajaran dengan maksud untuk membuat cara berkomunikasi lebih efektif dan efisien. Dengan penggunaan alat-alat ini guru dan siswa dapat berkomunikasi lebih mantap dan hidup serta interaksinya bersifat banyak arah.

Media mengandung pesan sebagai perangsang belajar dan dapat menumbuhkan motivasi belajar sehingga siswa tidak menjadi bosan dalam meraih tujuan-tujuan belajar. Apapun yang disampaikan oleh guru sebaiknya menggunakan media, paling tidak yang digunakannnya adalah media verbal yang berupa kata-kata yang diucapkan dihadapan siswa.

Menurut Daryanto (1993) bahwa media adalah alat yang dapat membantu proses belajar mengajar yang berfungsi memperjelas makna pesan yang disampaikan sehingga tujuan pengajaran dapat disampaikan dengan lebih baik dan lebih sempurna.

Media dalam kawasan teknologi pendidikan merupakan sumber belajar yang berupa gabungan dari bahan dan peralatan. Bahan di sini merupakan barang-barang yang biasanya disebut perangkat lunak atau software yang di dalamnya terkandung pesan-pesan untuk disampaikan dengan mempergunakan peralatan (Sadiman, 2002: 19).

Kata media berasal dari kata medium yang secara harfiah berarti perantara atau pengantar pesan dari pengirim ke penerima pesan (Sadiman, 2002: 6). AECT (Association of Education and Communication Technology) memberikan batasan tentang media sebagai segala bentuk dan saluran yang digunakan orang untuk menyalurkan pesan atau informasi. Briggs (1970) dalam Sadiman (2002: 6) menyatakan bahwa media adalah segala alat fisik yang dapat menyajikan pesan serta merangsang siswa untuk belajar. Sedangkan NEA (National Education Association) menyatakan bahwa media adalah bentuk-bentuk komunikasi baik tercetak maupun audio-visual serta peralatannya. Media hendaknya dapat dimanipulasi, dilihat, didengar dan dibaca.

Dari beberapa batasan pengertian media tersebut di atas, maka dapat disimpulkan bahwa media adalah segala sesuatu yang dapat digunakan untuk menyalurkan pesan dari pengirim ke penerima sehingga dapat merangsang pikiran, perasaan, perhatian dan minat serta perhatian siswa sedemikian rupa sehingga terjadi proses belajar.

\section{Manfaat Media Pembelajaran}

Hamalik (1986) mengemukakan bahwa pemakaian media pembelajaran dalam proses belajar mengajar dapat membangkitkan keinginan dan minat yang baru, membangkitkan motivasi dan rangsangan kegiatan belajar, dan bahkan membawa pengaruh-pengaruh psikologis terhadap siswa. Penggunaan media pembelajaran akan sangat mem- 
bantu keefektifan proses belajar mengajar dan penyampaian pesan dan isi pelajaran pada saat itu. Media pembelajaran juga dapat membantu siswa meningkatkan pemahaman, menyajikan dengan menarik dan terpercaya, memudahkan penafsiran data, dan memadatkan informasi.

Sudjana \& Rivai (2005) mengemukakan manfaat media pembelajaran dalam proses belajar siswa, yaitu:

a. Pengajaran akan lebih menarik perhatian siswa sehingga dapat menumbuhkan motivasi belajar.

b. Bahan pengajaran akan lebih jelas maknanya sehingga dapat lebih dipahami oleh siswa dan memungkinkannya menguasai dan mencapai tujuan pengajaran

c. Metode mengajar akan lebih bervariasi, tidak semata-mata komunikasi verbal melalui penuturan kata-kata oleh guru, sehingga siswa tidak bosan dan guru tidak kehabisan tenaga, apalagi kalau guru mengajar pada setiap jam pelajaran.

d. Siswa dapat lebih banyak melakukan kegiatan belajar sebab tidak hanya mendengarkan uraian guru, tetapi juga aktivitas lain seperti mengamati, melakukan, mendemonstrasikan, memerankan, dan lain-lain

Menurut Kemp \& Dayton (1985: 3-4) dampak positif dari penggunaan media pembelajaran adalah sebagai berikut: a) Penyampaian pelajaran menjadi lebih baku. b) Pengajaran bisa lebih menarik. c) Pembelajaran menjadi lebih interaktif dengan diterapkannya teori belajar dan prinsip-prinsip psikologis yang diterima dalam hal partisipasi siswa, umpan balik dan penguatan. d) Lama waktu pengajaran yang diperlukan dapat dipersingkat e) Kualitas hasil pelajaran dapat ditingkatkan bilamana integrasi kata dan gambar sebagai media pengajaran dapat mengko- munikasikan elemen-elemen pengetahuan dengan cara yang terorganisasikan dengan baik, spesifik dan jelas. f) Pengajaran dapat diberikan kapan dan di mana diinginkan atau diperlukan terutama jika media pengajaran dirancang untuk penggunaan secara individu. g) Sikap positif siswa terhadap apa yang mereka pelajari dan terhadap proses belajar dapat ditingkatkan. h) Peran guru dapat berubah ke arah yang lebih positif; beban guru untuk penjelasan yang berulang-ulang mengenai isi pelajaran dapat dikurangi bahkan dihilangkan sehingga ia dapat memusatkan perhatian kepada aspek penting lain dalam proses belajar mengajar.

Sejak tahun 50-an sampai tahun 70-an tidak kurang dari 20 rangkuman penelitian penggunaan alat peraga dalam pengajaran matematika. Di antaranya yang paling lengkap adalah rangkuman Dr. Higgins dan Dr.Suydan tahun 1976, yang antara lain menyimpulkan:

1) pemakaian alat peraga dalam pengajaran matematika itu berhasil atau efektif dalam mendorong prestasi siswa.

2) Sekitar $60 \%$ lawan $10 \%$ menunjukkan keberhasilan yang meyakinkan dari belajar dengan alat peraga terhadap yang tidak memakai. Besarnya persentase yang menyatakan bahwa penggunaan alat peraga itu paling tidak hasil belajarnya sama dengan yang tidak menggunakan alat peraga adalah $90 \%$.

3) Manipulasi alat peraga itu penting bagi siswa SD di semua tingkatan.

4) Ditemukan sedikit bukti bahwa manipulasi alat peraga itu hanya berhasil ditingkat yang lebih rendah (berhasil disemua tingkatan).

Dalam hubungan dengan penggunaan media pada waktu berlangsungnya pengajaran setidak-tidaknya media digunakan guru pada situasi sebagai berikut: 
a. Perhatian siswa terhadap pengajaran sudah berkurang akibat kebosanan mendengarkan uraian guru. Penjelasan secara penuturan secara verbal oleh guru mengenai bahan pengajaran biasanya sering membosankan apalagi bila cara guru menjelaskannya tidak menarik. Dalam situasi ini tampilnya media akan mempunyai makna bagi siswa dalam menumbuhkan kembali perhatian belajar siswa.

b. Bahan pengajaran yang dijelaskan guru kurang dipahami siswa. Dalam situasi ini sangat bijaksana apabila guru menampilkan media untuk memperjelas pemahaman siswa mengenai bahan pengajaran. Misalnya menyajikan bahan dalam bentuk visual melalui gambar, grafik, bagan atau model-model yang berkenaan dengan isi bahan pengajaran.

c. Terbatasnya sumber pengajaran. Tidak semua sekolah mempunyai buku sumber, atau tidak semua bahan pengajaran ada dalam buku sumber. Situasi ini menuntut guru untuk menyediakan sumber tersebut dalam bentuk media. Misalnya peta atau globe dapat dijadikan sumber bahan belajar bagi siswa, demikian juga model, diorama, media grafis dan lain-lain.

d. Guru tidak bergairah untuk menjelaskan bahan pengajaran melalui penuturan kata-kata (verbal) akibat terlalu lelah disebabkan telah mengajar cukup lama. Dalam situasi ini guru dapat menampilkan media sebagai sumber belajar bagi siswa. Misalnya guru menampilkan bagan atau grafik dan siswa diminta memberi analisis atau menjelaskan apa yang tersirat dari gambar atau grafik tersebut, baik secara individual maupun secara kelompok.
Dengan memperhatikan cara menentukan jenis/kriteria media yang baik, penulis mencoba memberikan alternatif sebuah media pembelajaran untuk menjembatani siswa mempelajari Perkalian dan Pembagian serta Bangun Datar. Media yang dimaksud adalah garis bilangan dan papan berpaku.

\section{CONTOH PENGGUNAAN MEDIA PEMBELAJARAN SEBAGAI SA- RANA KOMUNIKASI DALAM PEMBELAJARAN MATEMATIKA SD}

Salah satu cara untuk meminimalkan hambatan komunikasi dalam pembelajaran adalah dengan menggunakan media pembelajaran yang tepat. Hal ini dikarenakan matematika mempunyai kajian yang bersifat abstrak. Menurut Dienes (Ruseffendi, 1997: 92-94), dengan belajar matematika manusia dapat menyelesaikan persoalan yang ada di masyarakat yaitu dalam berkomunikasi sehari-hari seperti berhitung, mengumpulkan, mengolah dan menyajikan data dengan menggunakan alat. Ini berarti bahwa media atau alat peraga dalam suatu pembelajaran matematika sangat menunjang. Nana Sudjana berpendapat bahwa dengan menggunakan alat peraga dapat menambah minat dan perhatian siswa untuk belajar serta memberikan pengalaman yang nyata dan dapat menumbuhkan kegiatan berusaha sendiri pada diri siswa (Sudjana, 1989: 100).

Pada dasarnya anak belajar melalui sesuatu yang konkrit. Untuk memahami konsep abstrak anak memerlukan benda-benda konkrit sebagai perantara atau visualisasinya. Konsep abstrak itu dicapai melalui tingkat tingkat belajar yang berbeda-beda, bahkan orang dewasa pun yang pada umumnya sudah dapat memahami konsep abstrak, pada keadaan tertentu sering memerlukan visualisasi. Nasution menyatakan bahwa maksud dan tujuan peragaan adalah memberikan variasi dalam cara guru 
mengajar dan memberikan lebih terwujud, lebih terarah untuk mencapai tujuan pembelajaran. Pada pembelajaran matematika pada konsep abstrak akan dapat dipahami dan tahan lama pada siswa bila belajar melalui berbuat dari pengertian, bukan hanya mengingatingat fakta.

Proses pembelajaran merupakan suatu kegiatan dalam melaksanakan kurikulum pada sebuah lembaga pendidikan, yang bertujuan mempengaruhi para siswa mencapai tujuan pendidikan yang telah ditetapkan. Tujuan pendidikan pada dasarnya mengantarkan para siswa menuju pada perubahan-perubahan tingkah laku baik intelektual, moral maupun sosial agar dapat hidup mandiri sebagai individu dan makhluk sosial. Dalam mencapai tujuan tersebut siswa berinteraksi dengan lingkungan belajar yang diatur guru melalui proses pembelajaran. Lingkungan belajar yang diatur oleh guru mencakup tujuan pengajaran, bahan pengajaran, metodologi pembelajaran dan penilaian pembelajaran. Unsur-unsur tersebut biasa dikenal dengan komponen-komponen pembelajaran. Tujuan pengajaran adalah rumusan kemampuan yang diharapkan di-miliki para siswa setelah ia menempuh berbagai pengalaman belajarnya (pada akhir pembelajaran).

Bahan pembelajaran adalah seperangkat materi keilmuan yang terdiri atas fakta, konsep, prinsip, generalisasi suatu ilmu pengetahuan yang bersumber dari kurikulum dan dapat menunjang tercapainya tujuan pengajaran. Metodologi pengajaran adalah metode dan teknik yang digunakan guru dalam melakukan interaksinya dengan siswa agar bahan pengajaran sampai kepada siswa, sehingga siswa menguasai tujuan pengajaran.

Dalam metodologi pengajaran ada dua aspek yang paling menonjol sebagai alat bantu dalam mengajar yakni metode dan media pembelajaran. Sedangkan penilaian adalah alat untuk mengukur atau menentukan taraf tercapai tidaknya tujuan pengajaran. Dari uraian di atas dapat disimpulkan bahwa kedudukan media pembelajaran sebagai alat bantu pembelajaran ada dalam komponen metodologi, sebagai salah satu lingkungan belajar yang diatur oleh guru. Berikut ini merupakan salah satu contoh media pembelajaran yang dapat digunakan pada materi perkalian dan pembagian di SD.

Dalam menjelaskan perkalian perlu dikomunikasikan konsep bahwa perkalian merupakan penjumlahan berulang sedangkan pembagian merupakan pengurangan yang berulang. Menanamkan konsep ini sangat perlu dilakukan karena tidak mudah menerima materi perkalian secara langsung bagi siswa SD. Banyak media atau alat peraga yang dapat digunakan untuk mengkomunikasikan ide dan gagasan dari konsep perkalian dan pembagian. Dalam tulisan ini akan disinggung tentang garis bilangan. Sebagai contoh dalam mengkomunikasikan operasi perkalian $3 \times 5$ dapat dilakukan dengan mengelompokkan lima satuan sebanyak tiga kali dengan menggunakan karet gelang (titik awal dari nol 0) sehingga terdapat tiga kelompok dimana masing-masing kelompok berisi lima satuan, ini berarti $5+5+5$ seperti di bawah ini:

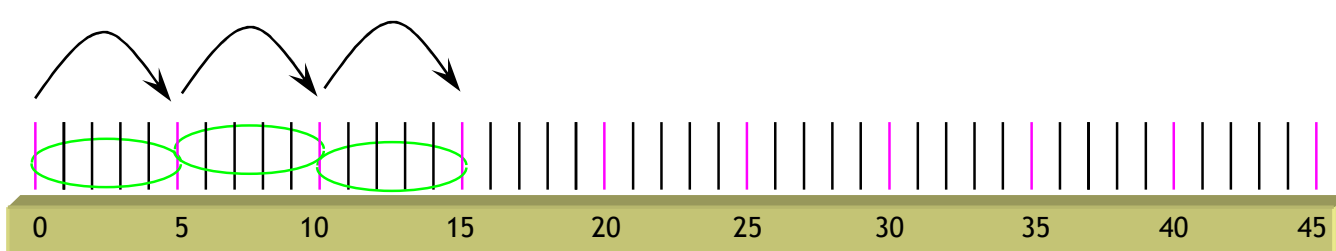




\section{Gambar 1. Garis bilangan 1}

perhatikan bilangan pada garis bilangan yang ditunjukkan pada ujung terakhir yaitu 15 .

Sedangkan untuk menjelaskan operasi pembagain 12:3 adalah dengan mengelompokkan tiga satuan dengan menggunakan karet gelang, berawal dari 12 hingga 0 . Hasilnya diperoleh empat kelompok. Banyaknya kelompok merupakan hasilnya yaitu 4 (empat) kelompok yang masing-masing berisi tiga satuan.

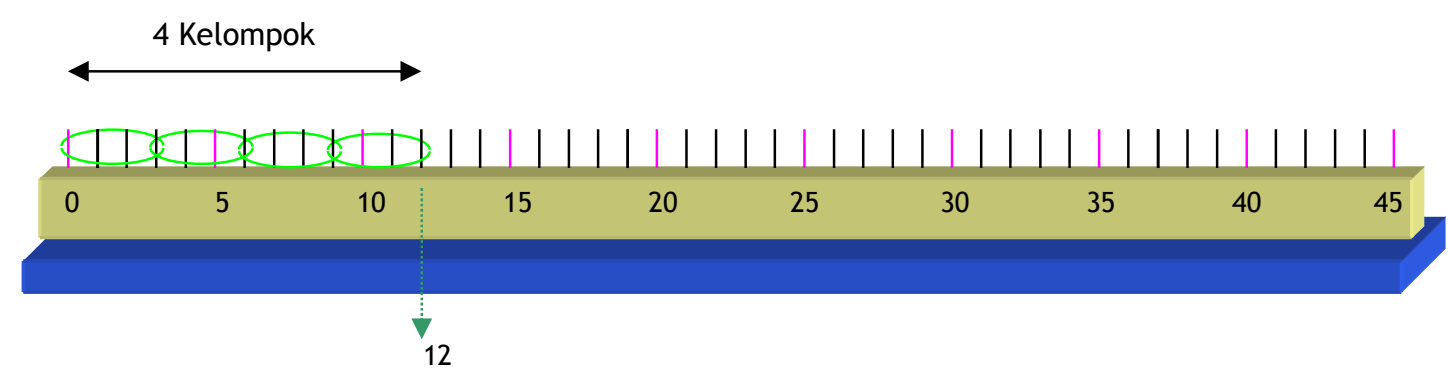

Gambar 2. Garis bilangan 2

Garis bilangan juga dapat dilakukan untuk operasi penjumlahan dengan cara melompokkan satuan-satuan bilangan yang dijumlahkan dengan menggunakan karet gelang, misalnya: $3+5$ dimana pangkal bilangan kedua terletak pada ujung bilangan pertama demikian seterusnya. bilangan pada garis bilangan yang ditunjukkan pada ujungnya.

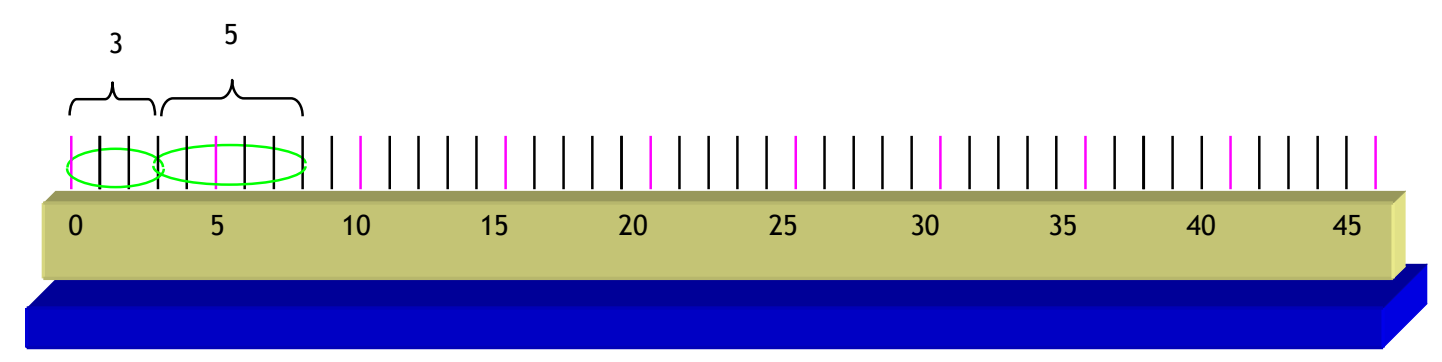

Gambar 3. Garis bilangan 3

Operasi pengurangan dapat dilakukan dengan cara yang sama dengan operasi penjumlahan hanya arahnya berlawanan.

Contoh lain yang akan disampaikan adalah media papan berpaku yang bermanfaat untuk pengenalan bangun datar, keliling bangun datar, dan menentukan/menghitung luas bangun datar.
Guru dapat menyediakan papan berpaku di depan kelas dengan cara digantung atau disandarkan pada benda lain. Papan berpaku dilengkapi sejumlah karet gelang dengan 4 warna yang berbeda serta dilengkapi pula dengan kertas bertitik atau kertas berpetak. Secara klasikal guru mengkomunikasikan di depan kelas 
cara membentuk bangun datar dan siswa dianjurkan untuk membentuk bangun datar sesuai dengan kreativitas masingmasing. dan menggambarkan pada kertas berpetak. Setelah itu kemudian guru memperkenalkan nama-nama bangun datar yang telah dibuat oleh siswa (jangan memaksakan semua diberi nama, kecuali bangun-bangun dasar yang sudah biasa, segiempat, persegi, persegipanjang, jajargenjang, trapesium, trapesium samasisi, trapesium samakaki, belah ketupat,

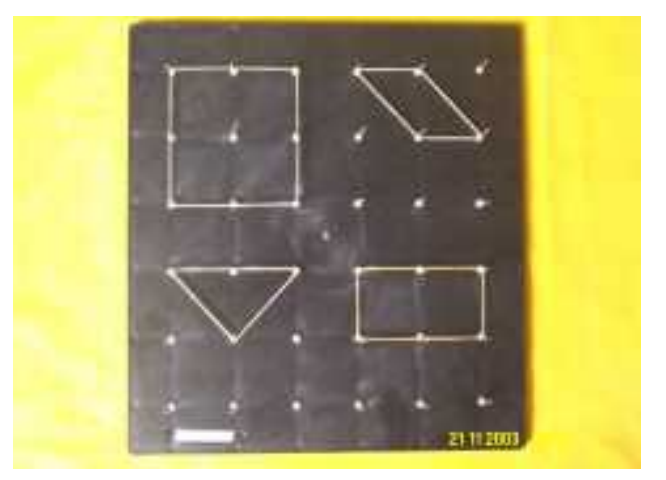

Gambar 4. Papan berpaku

layang-layang, segitiga siku-siku, segitiga samakaki, segitiga samasisi, segitiga tumpul, segitiga lancip, segitiga sembarang, segilima, segienam, dsb.)

\section{KRITERIA PEMILIHAN MEDIA PEMBELAJARAN}

Penggunaan media tidak dilihat atau dinilai dari segi kecanggihan medianya tetapi yang lebih penting adalah fungsi dan peranannya dalam membantu mempertinggi proses pembelajaran. Kadangkala seorang guru harus mampu melakukan manipulasi yang menyenangkan dalam menentukan media pembelajaran yang dapat mengkomunikasikan ide dan gagasan yang dimilikinya. Bahan Manipulatif adalah perangkat pembelajaran yang berupa benda fisik yang dapat dimanipulasi yang dapat memodelkan dan memperagakan konsep serta proses matematika. Melalui bahan manipulatif tersebut diharapkan siswa dapat belajar sambil bermain sehingga anak dapat secara aktif belajar dengan aktifitas yang menyenangkan( Soeharjo, 2006).

Kemp, 1974 berpendapat bahwa media yang baik memenuhi 3 (tiga syarat) yaitu: Functional (berfungsi dengan baik), Fun (menyenangkan), Fit us (menjadi sumber pendukung). Kemp, 1974 juga menyatakan aspek-aspek yang perlu diperhatikan dalam membuat media pengajaran adalah bahwa media itu memenuhi kriteria ASSURE:

1. Menganalisa Pebelajar (Analyze Learner)

2. Memiliki Tujuan Pembelajaran (State the Objective)

3. Media yang dipilih sesuai dengan metode dan bahan ajar (Select Media, Method and Materials)

4. Media dapat tepat digunakan (Utilize Media)

5. Membutuhkan partisipasi pelajar (Require Learner Patricipation)

6. Media tersebut dapat di evaluasi dan di revisi (Evaluate and Revise)

Dengan kriteria pemilihan media di atas, guru dapat lebih mudah menggunakan media mana yang dianggap tepat untuk membantu mempermudah tugas-tugasnya sebagai pengajar.

\section{PENUTUP}

Selain mampu memecahkan masalah matematika dengan baik, Standar Kompetensi dan Kompetensi Dasar matematika mulai tingkat sekolah dasar hingga sekolah menengah atas disusun dengan maksud mengkomunikasikan ide atau gagasan dengan menggunakan simbol, tabel, diagram, dan media lain. Sehubungan dengan itu siswa sekolah dasar berada pada perpindahan tahap konkret ke tahap yang lebih abstrak dimana mengkomunikasikan ide-ide dan gagasan matematika dalam tahap tersebut sangat baik dilakukan dengan bantuan media pembelajaran. Dengan media pembela- 
jaran kelancaran komunikasi dan informasi dalam matematika dapat dilakukan dengan tepat. Guru dapat menggunakan media mana yang dianggap tepat untuk membantu mempermudah tugas-tugasnya sebagai pengajar. Penggunaan media

\section{DAFTAR RUJUKAN}

Cockroft, W.H.1986. Mathematics Counts. London: HMSO

Daryanto. 1993. Media Visual untuk Pengajaran Teknik. Tarsito Bandung

Hamalik, Oemar. 1986. Pendekatan Belajar Mengajar Berdasarkan CBSA. Bandung Sinar Baru.

Kemp, Jerrol E. 1994. Proses Perancangan Pengajaran. Terjemahan. Bandung. ITB

NCTM 2000. Principles and Stan-darts for School Mathematics. Reston: NTCM

Pusat Pengembangan Penataran Guru Matematika, 2004, Kumpulan Alat Peraga Matematika (CD), 2004 ,Yogyakarta, Depdiknas

Peraturan Menteri Pendidikan Nasional Republik Indonesia Nomor 22 Tahun 2006 tentang Standar Isi Untuk Satuan Pendidikan Dasar Dan Menengah.

Russefendi, E.T., dkk. 1993. Materi Pokok Pendidikan Matematika 3. Jakarta. Universitas Terbuka. tidak dilihat atau dinilai dari segi kecanggihan medianya tetapi yang lebih penting adalah fungsi dan peranannya dalam membantu mempertinggi kualitas komunikasi dan informasi proses pembelajaran.

Ruseffendi, ET. 1997. Pendidikan Matematika 3. Jakarta: Univesitas Terbuka Depdikbud.

Sadiman, Arief. 2002. Media Pendidikan. Jakarta: Raja Grafindo Persada.

Sudjana, N. 1989. Cara Belajar Siswa Aktif dalam Proses Belajar Mengajar. Bandung : Sinar Baru.

Sudjana, Nana., Ahmad Rivai. 2005. Media Pengajaran. Bandung. Sinar Baru Algensindo

Shadiq, Fajar. 2004. Pemecahan Masalah, Penalaran dan Komunikasi (Modul Diklat Instruktur Pengembangan Matematika SMA Jenjang Dasar). PPPG Matematika. Yogyakarta.

Soeharjo. 2005. Peningkatan Kualitas Pembelajaran Soal Cerita Matematika SD melalui penggunaan Bahan Manipulatif. Journal Sekolah Dasar, th IV Nomor 2, November 2005. Universitas $\mathrm{Ne}$ geri Malang

Suriasumantri, J.S. 1988. Filsafat Ilmu. Jakarta: Sinar Harapan. 